\title{
Glucose inhibits angiogenesis of isolated human pancreatic islets
}

\author{
S Dubois ${ }^{1}$, A M Madec ${ }^{1}$, A Mesnier ${ }^{1}$, M Armanet ${ }^{2}, \mathrm{~K} \mathrm{Chikh}^{3}$, T Berney ${ }^{2}$ \\ and Ch Thivolet ${ }^{1,4}$ \\ ${ }^{1}$ Inserm U870/Inra 1235, Faculté de Médecine Lyon sud, 69600 Oullins, France \\ ${ }^{2}$ Cell Isolation and Transplantation Centre, Geneva University Hospital, Geneva, Switzerland \\ ${ }^{3}$ Department of Biochemistry, CHLS, HCL, 69310 Lyon, France \\ ${ }^{4}$ Department of Endocrinology and Diabetes, CL, UCB Lyon 1, 69310 Lyon, France \\ (Correspondence should be addressed to Ch Thivolet; Email: charles.thivolet@chu-lyon.fr)
}

\begin{abstract}
Owing to strong interactions between pancreatic islets and the surrounding capillary network, we hypothesized that high glucose concentrations might affect key angiogenesis factors from isolated human islets, thus contributing to $\beta$-cell failure in diabetes. Human islets from eight distinct donors were studied following $96 \mathrm{~h}$ in culture in the presence of normal $(5.5 \mathrm{mmol} / \mathrm{l})$ or high $(16.7 \mathrm{mmol} / \mathrm{l})$ glucose concentrations. Similar studies were performed with HUVECs. Human angiogenesis-related genes and corresponding proteins were studied by real-time quantitative PCR (RT-qPCR) and protein arrays respectively. Angiogenesis and proliferation assays were also performed with HUVECs under the same culture conditions. RT-qPCR and proteome analysis of human islets incubated with $16.7 \mathrm{mM} / \mathrm{l}$ glucose revealed a significant decrease in pro-angiogenic factors including vascular endothelial growth factor (VEGF) mRNA by $20 \%$ and VEGF protein levels by $42 \%$ as well as additional proteins such as fibroblast growth factor- 4 by $41 \%$, MMP9 by $18 \%$, monocyte chemoattractant protein-1 by $21 \%$, and prolactin by $25 \%$. In contrast, we observed a $17 \%$ increase in thrombospondin-1 (TSP-1, listed as THBS1 in the HUGO database) and a $37 \%$ increase in angiotensinogen gene expression levels, but neither angiotensin-converting enzyme nor angiotensin II type 1 receptor gene expression was affected. The amounts of anti-angiogenic proteins such as TSP-1 and serpin B5/maspin were also increased by 70 and $98 \%$ respectively as well as endostatin by $63 \%$. Angiogenesis assays of HUVECS in the presence of high glucose concentrations revealed a $30 \%$ decrease in tree-like tubular network formation. These data suggest that glucose reduces key factors of islet angiogenesis, which might exacerbate $\beta$-cell failure.
\end{abstract}

Journal of Molecular Endocrinology (2010) 45, 99-105

\section{Introduction}

The pancreas is a complex organ closely associated with an important network of blood capillaries and particularly surrounding the islets of Langerhans. Blood capillaries are important component in the paracrine regulations and exchanges between various tissues involved in glucose metabolism via nutritional or hormonal signals (Ballian \& Brunicardi 2007). Angiogenesis constitutes a mechanism where new blood vessels are formed by budding of existing prevessels, which can be activated under physiological but also pathological conditions such as inflammatory processes. During diabetes, the angiogenic answer to ischemia differs according to tissue, which is either excessive in certain organs such as the retina with neovascularization, compromising the vision, or defective in other organs such as the heart, determining the severity of ischemia during infarction (Pandya et al. 2006). This mechanism is controlled by many pro- or anti-angiogenic factors, which are in close coordination with one another (Distler et al. 2003). In the endocrine pancreas, the local renin-angiotensin systems (RAS) as well as factors involved in angiogenesis are important regulators of islet structure and function mainly through regulation of local blood flow (Leung \& Carlsson 2005). Increased insulin requirements promote $\beta$-cell replication and neogenesis leading to increase cell size and number as well as the formation of new blood vessels to preserve islet cytoarchitecture and function. Several pieces of evidence suggest abnormal islet angiogenesis in type 2 diabetes. The importance of islet microvessels in $\beta$-cell function is also clearly illustrated in type 1 diabetes since survival and optimal engraftment of transplanted islets in the liver depend on graft vascular density and blood flow (Olsson \& Carlsson 2006). The present study aimed to investigate the effects of glucose on human $\beta$-cell function and endothelial cells. 


\section{Materials and methods}

\section{Subjects}

Human pancreatic islets from eight organ donors (age $=50 \pm 9$ years; body mass index $=23 \cdot 6$ $\pm 1 \cdot 8 \mathrm{~kg} / \mathrm{m}^{2}$; purity of islet preparations $=70 \pm 9 \%$ ) have been obtained through the Cell Isolation and Transplantation Centre from the Geneva University Hospital with prior consent for research use.

\section{Cell cultures}

Upon isolation, islets were cultured in CMRL 1066 containing $2.5 \%$ human serum albumin at $37^{\circ} \mathrm{C}$ in a $5 \%$ $\mathrm{CO}_{2}$ incubator. After a short period (1-3 days), human islets (10.000 Islet Equivalents (IEQ)) were shipped to our laboratory and immediately cultivated (1000 IEQ/experimental condition) at $37^{\circ} \mathrm{C}, 5 \% \mathrm{CO}_{2}$ in DMEM supplemented with $10 \%$ fetal bovine serum, $100 \mathrm{U} / \mathrm{ml}$ penicillin $(\mathrm{P}), 0 \cdot 1 \mathrm{mg} / \mathrm{ml}$ streptomycin $(\mathrm{S})$ and $2 \%$ HEPES $(1 \mathrm{mmol} / \mathrm{l})$. Islets were cultivated for 4 days at $37^{\circ} \mathrm{C}, 5 \% \mathrm{CO}_{2}$ in the above-described medium containing either 5.5 or $16.7 \mathrm{mmol} / 1$ glucose $(n=8)$. HUVECs were a gift of Geneva Hospital and were cultivated in endothelial medium (Promocell) containing glucose in the same culture conditions as for human islets. In all experiments, both RNA and proteins were extracted, except for HUVECs where only RNA was extracted. Real-time PCR and/or protein arrays evaluated markers involved in inflammation, and angiogenesis was performed. Media from pancreatic islet cultures were kept frozen and analyzed by IRMA to evaluate insulin secretion. Insulin secretion studies were performed using comparable islet numbers. Aliquots of supernatants were stored at $-20^{\circ} \mathrm{C}$ until insulin concentrations were measured by a highly specific IRMA (BI-insulin IRMA; Cis-Bio International, Gif sur Yvette, France) that cross-reacts with human proinsulin for $<0.0001 \%$ and C-peptide for $<0.0003 \%$. Insulin levels were normalized to protein concentrations of cell extracts and expressed in mUI/l per prot.

\section{RNA extraction and real-time PCR}

We focused our interest on vascular endothelial growth factor-A (VEGFA) gene expression and on genes that code for proteins that interfere with the fixation of VEGF to its receptor VEGFR2 (listed as KDR in the HUGO database) such as thrombospondin-1 (TSP-1, THBS1) and tissue inhibitor of metalloproteinase 3 (TIMP3) and ephrin A5 (EFNA5), which is proangiogenic and involved in $\beta$-cell interactions. Since factors of local RAS may be important regulators of islet structure and function, gene expressions of angiotensinogen $(A G T)$, angiotensin receptor 1 (ATIR, AGTR1), and angiotensin-converting enzyme $(A C E)$ were also studied. To monitor $\beta$-cell function and levels of cell apoptosis, we compared levels of gene expressions of insulin (INS), nuclear factor $\kappa-\mathrm{B}(N F \kappa B)$, caspase 3 (CASP3), the cell survival phosphatidylinositol 3-kinase $(P I 3 K) / A K T$, and FAS (FAS). Levels of transcripts were determined by quantitative RT-PCR using eight independent islet cell preparations. Total RNA was obtained following the method of Chomczynski \& Sacchi (1987) using the total RNA extraction kit from Qiagen. RNA quantification was performed using a Nanodrop Spectrophotometer (Labtech Technologies, Palaiseau, France). SYBR Green PCR technique was used to quantify the mRNA level of each gene (Abgene, Courtaboeuf, France). Briefly, cDNA was generated for each sample by reverse transcription of mRNA $(1 \mu \mathrm{g})$ using superscript III. PCR was carried out using 2 ng of template cDNA on a Rotor-Gene 6000 Detection System (Corbett Research, Courtaboeuf, France) at $50{ }^{\circ} \mathrm{C}$ for $2 \mathrm{~min}, 95^{\circ} \mathrm{C}$ for $10 \mathrm{~min}$, followed by 40 cycles of $95{ }^{\circ} \mathrm{C}$ for $15 \mathrm{~s}$ and $60{ }^{\circ} \mathrm{C}$ for $1 \mathrm{~min}$. Results from cells cultured at $5.5 \mathrm{mmol} / \mathrm{l}$ glucose were used as baseline. Each value was first normalized to the control gene $T B P$ to yield a relative abundance. All experiments were performed at least three times with a good agreement among individual experiments. Primer sequences of all selected genes are listed in Table 1.

\section{Proteome analysis}

To extend our analysis to more than 50 factors involved in angiogenesis, we then applied our experimental samples to a specific protein array. Proteins were isolated from human islets $(n=3)$ cultured under various conditions. Human angiogenesis-related proteins (55 studied) were then studied. Analysis was performed according to the manufacturer's protocol ( $R \& D$ Systems, Minneapolis, MN, USA). Briefly, antibodies were spotted in duplicate on nitrocellulose membranes. Protein lysates were diluted and mixed with a cocktail of biotinylated antibodies. The sample/antibody mixture was then incubated on the membrane. Antigenantibody complexes were revealed by its cognate immobilized capture antibody. Streptavidin-HRP and chemiluminescent detection reagents were used for quantification. Array data on developed X-ray films were quantified with software adapted for image analysis (ImageJ; NCBI, Bethesda, MD, USA). Negative control spots were used as background values to normalize each protein spot. We compared the relative changes in the average signal (pixel density) of duplicate spots. Three independent experiments were performed.

\section{Proliferation and angiogenesis assay}

Primary endothelial cells (HUVECs) were cultivated for 4 days in endothelial medium containing either 5.5 or $16.7 \mathrm{mmol} / 1$ D-glucose at $37^{\circ} \mathrm{C}, 5 \% \mathrm{CO}_{2}$. At day 3 of the 
Table 1 Sequences of primers used for the RT-qPCR

Primer sequence (forward)

Genes
ACE
AGT
AT1R
CASP3
EFNA5
FAS
INS
NFKB
PI3K
TBP
TIMP3
TSP-1
VEGFA

5'-CCGAAACGAAACCCACTTTG-3'

5'-TTCTGCACACCGAGCTGAAC-3' 5'-AGCCAGCGTCAGTTTCAACC-3' 5'-CAGATGTCGATGCAGCAAAC-3' 5'-TACATCTCCTCTGCAATCCC-3' 5'-GCATCTGGACCCTCCTACCT-3' 5'-GGGGAACGAGGCTTCTTCTA-3' 5'-GCACCTAGCTGCCAAAGAAG-3' 5'-TGACGCTTTCAAACGCTATC-3' 5'-TGGTGTGCACAGGAGCCAAG-3' 5'-CCTTCTGCAACTCCGACATC-3' 5'-TCCGCAAAGTGACTGAAGAG-3' 5'-TTGTACAAGATCCGCAGACG-3'
Primer sequence (reverse)

5'-GAACTGGAACTGCAGGACAA-3'3
5'-TGTTGGGTAAACTCTGTGGG-3'
5'-ACAAGCATTGTGCGTCGAAG-3'
5'-TGGCTCAGAAGCACACAAAC-3'
5'-ACGGTGTCATCTGCTGGTTC-3'
5'-CAGTCTGGTTCATCCCCATT-3'
5'-CACAATGCCACGCTTCTG-3'
5'-CATGGCAGGCTATTGCTCATC-3'
5'-CAGAGAGTACTCTTGCATTC-3'
5'-TTCACATCACAGCTCCCCAC-3'
5'-ATGTCGGTCCAGAGACACTC-3'
5'-GTAACTGAGTTCTGACAGTG-3'
5'-GTCACATCTGCAAGTACGTTCG-3'

treatment, ${ }^{3} \mathrm{H}$ thymidine $(1 \mu \mathrm{Ci} /$ well $)$ was added to the medium, and cells were incubated overnight at $37^{\circ} \mathrm{C}$, $5 \% \mathrm{CO}_{2}$. Following treatment cells, plates were kept at $-80{ }^{\circ} \mathrm{C}$ before performing the assay. ${ }^{3} \mathrm{H}$ thymidine radioactivity was measured in each well by using scintillation spectrometry. Cell proliferation was determined as percent counts compared to control (Gluc $5.5 \mathrm{mmol} / \mathrm{l}$ ). In vitro angiogenesis cell-based assay was performed using a kit (Cayman Chemicals, Ann Arbor, MI, USA). Briefly, HUVECs were cultivated in endothelial medium until confluence before seeding $\left(10^{4}\right.$ cells/well) in 96-well plates coated with extracellular matrix gel. Cells were then cultivated for 4 days in endothelial medium containing 5.5 or $16.7 \mathrm{mmol} / 1$ glucose. Following treatments, casein $(1 / 100 \mathrm{v} / \mathrm{v})$ was added to the cells and immediately visualized by using an inverted fluorescence microscope (Zeiss, Le Pecq, France) and FITC filter $(\lambda 520 \mathrm{~nm})$. Tubular network was evaluated by using Image J software and expressed as percent of control (Glc $5.5 \mathrm{mmol} / \mathrm{l}$ ). A stimulator (PMA, $64 \mathrm{nmol} / \mathrm{l}$ ) and inhibitor (JNJ-10198409, $0 \cdot 3 \mu \mathrm{mol} / \mathrm{l})$ have been used to validate the assay.

\section{Statistical analyses}

All values are presented as mean \pm s.E.M. Comparisons between group means were performed using unpaired $t$-tests as appropriate, and data were considered significant at $P<0 \cdot 05$. All variables were normally distributed as determined by Kolmogorov-Smirnov test.

\section{Results}

\section{No toxic effects are present in the model used}

Human islets were cultured for 4 days in normal or high concentrations of glucose. Insulin secretion was significantly increased by four times at $16.7 \mathrm{mmol} / 1$ glucose when compared to $5.5 \mathrm{mmol} / 1$ glucose $(55 \cdot 4 \pm 21 \cdot 4$ vs $13.5 \pm 11.5 \mathrm{mUI} / 1$ per prot from eight independent islet preparations, $P=0 \cdot 006)$. Similarly, we found that insulin gene expression was significantly increased by $70 \%(P=0.03)$ in islets treated with high glucose compared to islets treated with low glucose. Furthermore, we analyzed the expression of $N F K B, C A S P 3, F A S$, and cell survival PI3K/Akt pathway when islets were exposed to high versus low glucose concentrations. Under high glucose, no significant difference in gene expression was noticed (data not shown). Altogether, these results exclude the presence of toxic effects following our culture conditions.

\section{Glucose impairs angiogenesis and reduced the expression of key genes and proteins from isolated human islets}

To test whether glucose had the capacity to modulate the number of endothelial cells, indirect immunofluorescence studies were performed. As shown in Fig. 1, the number of CD31-positive cells (in red) was notably reduced when islets were incubated in media containing high glucose concentrations $(16 \cdot 7 \mathrm{mmol} / \mathrm{l})$. The mean \pm s.D. percentage of CD31+ cells among islet cells decreased from $9 \cdot 39 \% \pm 4 \cdot 3$ to $5 \cdot 22 \% \pm 2 \cdot 4$ during four independent experiments $(P<0 \cdot 05)$. This observation clearly indicated that glucose may have profound effects on human endothelial cells and islet microcirculation. Understanding the molecular basis of these effects was achieved by the study of key pathways. As shown in Fig. 2, islets cultured at $16.7 \mathrm{mmol} / 1$ glucose had a $20 \%$ reduction in $V E G F$ gene expression when compared to $5.5 \mathrm{mmol} / 1$ glucose $(P=0.05)$. Strikingly, this was associated with a $17 \%$ increase in TSP-1 and a $37 \%$ increase in AGT gene expression ( $P=0.04$ and $P=0.01$ respectively). Interestingly, neither $A C E$ nor $A T 1 R$ gene expression was affected 

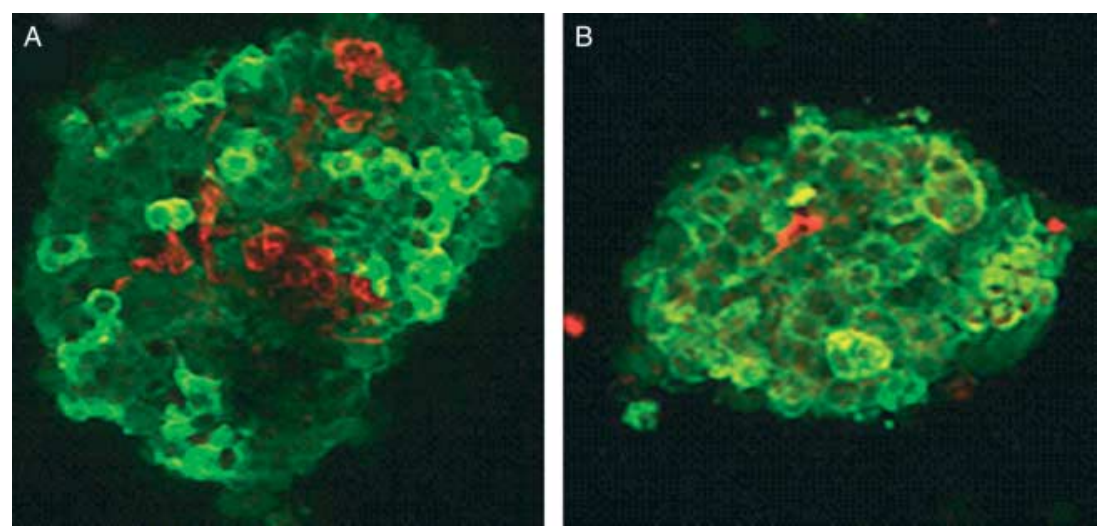

Figure $1 \mathrm{Immunostaining} \mathrm{of} \mathrm{human} \mathrm{islets} \mathrm{cultivated} \mathrm{in} \mathrm{medium} \mathrm{containing} 5 \mathrm{mmol} / \mathrm{l}(\mathrm{A})$ or $16.7 \mathrm{mmol} / \mathrm{l}(\mathrm{B})$ glucose. Islets were labeled with FITC anti-insulin and Cy3-conjugated anti-CD31 antibodies.

by high glucose concentrations $(1 \cdot 41 \pm 0.48$ vs 1.34 $\pm 0 \cdot 39$ and $0 \cdot 90 \pm 0 \cdot 18$ vs $0 \cdot 94 \pm 0 \cdot 22, P=$ NS respectively). No difference in gene expression was found for TIMP3 and EFNA5 when islets were treated with high glucose compared to low glucose $(2 \cdot 74 \pm 0 \cdot 92$ vs $2 \cdot 75 \pm 0 \cdot 91$, $2 \cdot 10 \pm 0 \cdot 88$ vs $2 \cdot 43 \pm 0 \cdot 98$, and $2 \cdot 12 \pm 0 \cdot 88$ vs $2 \cdot 14 \pm 0 \cdot 50$, $P=$ NS respectively).

We also performed proteome analysis of islets cultured at different glucose conditions as shown in Fig. 3. Results presented in Table 2 using three independent islet preparations indicated that exposition to high glucose concentrations impaired levels of multiple pro-angiogenic proteins and in contrast increased the expression of several anti-angiogenic factors. In line with our gene expression analyses, we observed a significant $42 \%$ decrease of VEGF protein expression $(P=0.002)$ and a $70 \%$ increase of TSP-1 protein expression that reached statistical significance $(P=0 \cdot 01)$. Several additional factors involved in endothelial cell migration and division were significantly reduced such as fibroblast growth factor-4 (FGF4) by $41 \%(P<0 \cdot 001)$ and hepatocyte growth factor (HGF) by $21 \%(P<0 \cdot 05)$. In addition, expression of proteins involved in extracellular matrix integrity such as MMP9 was reduced by an average of $18 \%$ $(P=0 \cdot 02)$. Levels of monocyte chemoattractant protein-1 (MCP-1) were also significantly reduced by $21 \%$ $(P<0 \cdot 05)$. Interestingly, we found that among growth factors, prolactin expression was decreased by $25 \%$ in the presence of $16.7 \mathrm{mmol} / 1$ glucose $(P=0 \cdot 01)$. On the other hand, several anti-angiogenic factors involved in endothelial dysfunction relative to their migration and their ability to form vascular tubes were significantly increased such as insulin-like growth factor-binding protein-1 (IGFBP1) by $63 \%(P=0 \cdot 003)$, maspin, a protein member of serpin family by $98 \%(P<0 \cdot 05)$, endostatin by $63 \%$ $(P<0 \cdot 05)$, and endoglin by $31 \%(P<0 \cdot 05)$. Levels of vasohibin increased by $38 \%$ without reaching statistical significance $(P=0 \cdot 07)$.
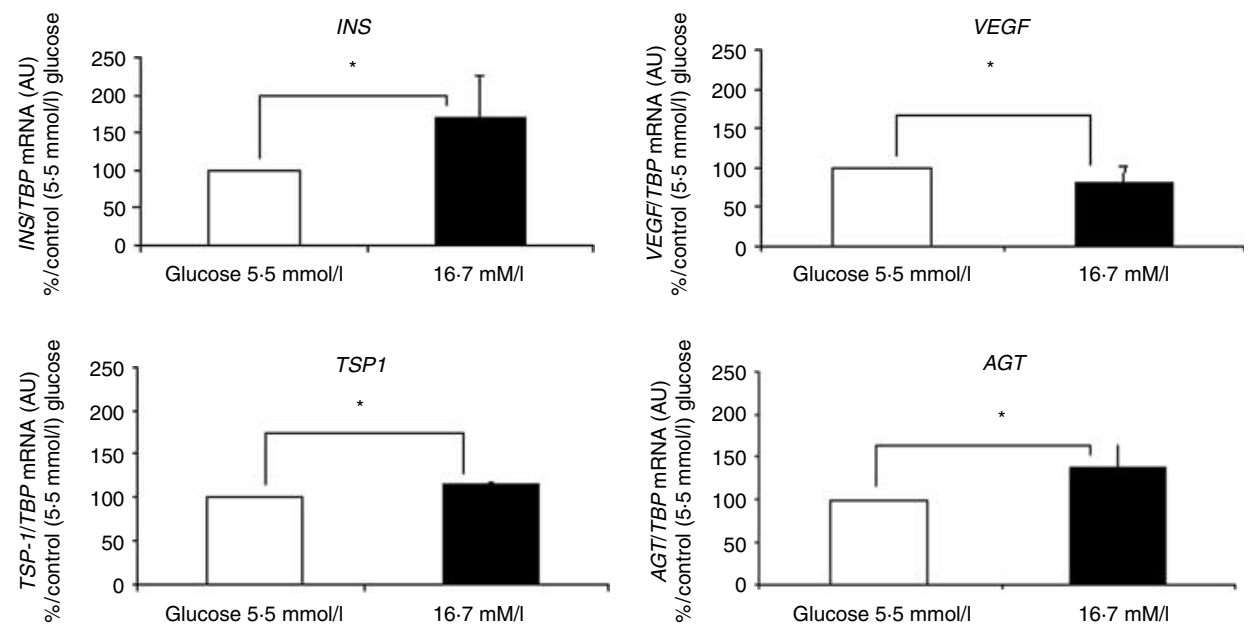

Figure 2 VEGF, INS, TSP-1, and AGT gene expression results adjusted to TBP mRNA levels of human islets cultured with 5.5 or $16.7 \mathrm{mmol} / \mathrm{l}$ glucose (4 days) from eight independent islet cell preparations. ${ }^{*} \leq 0.05$. 

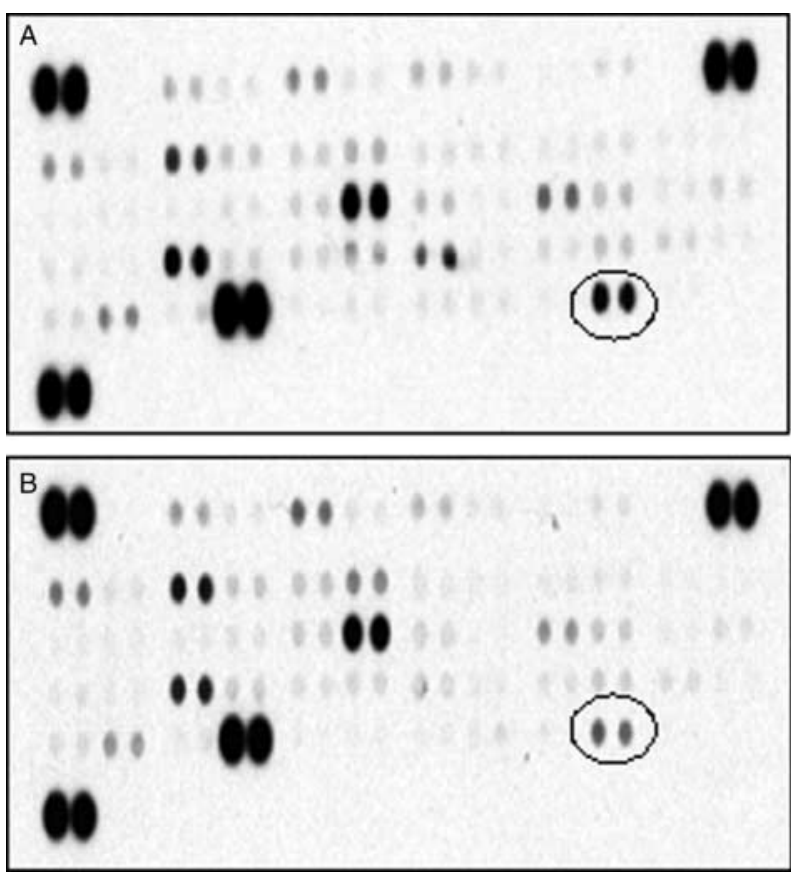

Figure 3 Comparison of protein array data of human islets cultured at $5.5 \mathrm{mM} / \mathrm{l}(\mathrm{A})$ or $16.7 \mathrm{mM} / \mathrm{l}(\mathrm{B})$ glucose. Average pixel density of the duplicate spots corresponding to VEGF protein (circled) was reduced by $56 \%$ in a representative experiment.

\section{Glucose impairs tubular network formation but not proliferation of HUVECs}

As shown in Fig. 4A and B, we observed that high glucose concentrations as compared to normal glucose levels induced a $30 \%$ decrease in tree-like tubular network formation $(P=0 \cdot 03, n=4)$. As expected, the angiogenic inhibitor (JNJ-10198409) significantly reduced tubular density by $80 \% \quad(P=0 \cdot 001)$, but angiogenic activator (PMA) did not increase tubular

Table 2 Regulation of protein expression of angiogenic factors from human islets treated with high glucose (16.7 mmol/l, 4 days) determined by protein array analysis from three independent islet preparations. Results expressed as percent of control islets (glucose $5.5 \mathrm{mmol} / \mathrm{l} 4$ days) reached statistical significance

\begin{tabular}{|c|c|c|c|}
\hline & $\begin{array}{l}\% \\
\text { decrease }\end{array}$ & $\begin{array}{l}\text { Anti-angiogenic } \\
\text { markers }\end{array}$ & $\begin{array}{l}\% \\
\text { increase }\end{array}$ \\
\hline \multicolumn{4}{|c|}{$\begin{array}{l}\text { Pro-angiogenic } \\
\text { markers }\end{array}$} \\
\hline FGF4 & $41 \pm 17^{\dagger}$ & Endoglin & $31 \pm 40^{*}$ \\
\hline HGF & $21 \pm 17^{*}$ & Endostatin & $63 \pm 41^{*}$ \\
\hline MCP-1 & $21 \pm 22^{*}$ & IGFBP1 & $63 \pm 24^{\dagger}$ \\
\hline MMP9 & $18 \pm 18^{*}$ & Maspin & $98 \pm 64^{*}$ \\
\hline Prolactin & $25 \pm 16^{\dagger}$ & TSP-1 & $70 \pm 66^{*}$ \\
\hline VEGF & $42 \pm 20^{\dagger}$ & Vasohibin & $38 \pm 43$ \\
\hline
\end{tabular}

density $(P=\mathrm{NS})$. However, we found that proliferation of HUVECs measured by using ${ }^{3} \mathrm{H}$ thymidine incorporation was not influenced by glucose as compared to normal glucose levels ( $3065 \pm 1100$ vs $2496 \pm 729$ c.p.m. (high versus low glucose, $n=3, P=\mathrm{NS}$ )).

\section{Discussion}

The effects of glucose on endothelial cells are heterogeneous depending on tissues, underlying many chronic diabetic complications. However, at the pancreatic level, little is known on the specific effects of glucose on islet endothelium. The islet vascular system is critical for intercellular interactions and $\beta$-cell function. Using isolated human islets, we found that chronic exposition to high glucose levels impairs several important steps of islet angiogenesis. No direct toxic effect was noticed even if we cannot exclude an apoptotic effect of glucose on endothelial cells surrounding the islets.

Isolation of pancreatic islets by enzymatic digestion disrupts the islet vascular connection and microvascular networks. The reconstitution of islet endothelial cells requires adequate culture conditions and growth factors, and is an interesting model to explore islet angiogenesis in vitro. VEGF and cognate receptors are critical for angiogenesis. VEGFA is the most important hypoxia-driven mediator that regulates blood vessel growth (Neufeld et al. 1999) with differential roles attributed to VEGFR1 and -R2 (Shibuya 2006). We have therefore focused our research on VEGF and VEGFrelated genes both at the mRNA and protein levels. Already at $16.7 \mathrm{mmol} / \mathrm{l}$ glucose, VEGFA gene expression was reduced by $20 \%$ and protein levels by $42 \%$ in our experiments. VEGF synthesis was shown to be regulated by glucose using fibroblasts of $\mathrm{db} / \mathrm{db}$ mice as compared to wild-type mice (Lerman et al. 2003). Interestingly, mice with disrupted Vegfa gene specifically in $\beta$ cells had reduced islet vascular density glucose intolerance and impaired insulin secretion (Iwashita et al. 2007). However, insulin secretion in this model was also enhanced in vitro, thus indicating that VEGFA was not implicated in $\beta$-cell function. We observed that several factors involved in endothelial cell migration or extracellular matrix were down-regulated by glucose. Interestingly, a significant reduction of MMP9 expression was noticed. MMP9 is a zincdependent endopeptidase involved in angiogenesis through VEGFA accessibility (Bergers et al. 2000) and tumor growth (Memtsas et al. 2009). In addition, expression of $M C P-1$ was reduced. The CC chemokine MCP-1/CCL2 has both inflammatory and pro-angiogenic effects. It mediates recruitment of mononuclear cells, modulates monocyte and lymphocyte phenotype, and is known to increase collateral vessel formation during limb ischemia (Shireman 2007), and has an 


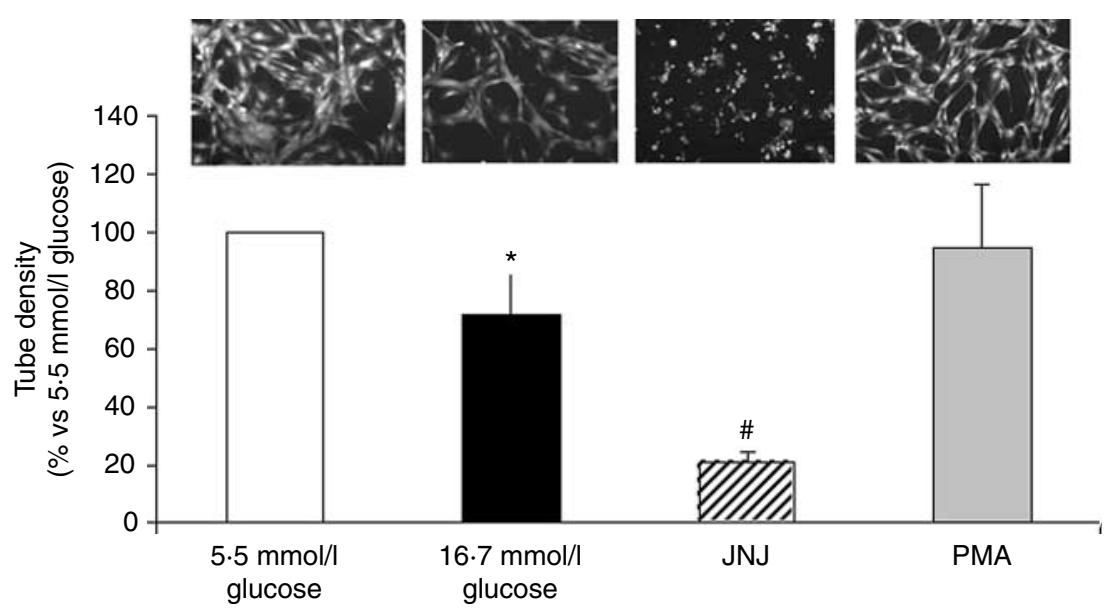

Figure 4 Upper panel: tree-like tubular network in HUVECs treated with $5.5 \mathrm{mmol} / \mathrm{l}(\mathrm{A})$ or $16.7 \mathrm{mmol} / \mathrm{l}$ glucose (B), angiogenesis activator PMA (C), or inhibitor JNJ (D). Lower panel: tube density expressed as percent of control ( $5.5 \mathrm{mmol} / /$ glucose). ${ }^{\star} P<0.05$; ${ }^{\sharp} P<0.001$.

important role in infarct healing and post-infarction remodeling (Xia \& Frangogiannis 2007). Using rat islets, it has been suggested that MCP-1 secretion could be induced by IL1 during an early phase of inflammatory response perhaps linked to islet isolation (Ehses et al. 2009). This was not confirmed using human islets (Welsh et al. 2005). In our experiments, islets were studied at least 6 days after isolation. The $21 \%$ reduction of MCP-1 protein in the presence of high glucose concentrations is therefore against an inflammatory response, and is concordant with the hypothesis that glucose impairs angiogenesis. Reduction of prolactin expression by high glucose is an interesting feature. Recent reports have demonstrated that prolactin enhanced human $\beta$-cell viability (Yamamoto et al. 2008) as well as $\beta$-cell proliferation through the PI3K signaling pathway (Hügl \& Merger 2007). During pregnancy, both pancreatic $\beta$ cells and islet endothelial cell display a highly reproducible physiological proliferation that requires the expression of prolactin receptor (Huang et al. 2009). From all these observations, reduction of prolactin levels by glucose is important to consider for both islet and endothelial cell functions.

In contrast, expression of anti-angiogenic factors was increased such as TSP-1 and AGT. TSP-1 is a secreted glycoprotein, member of the serine protease inhibitor family that binds to the extracellular matrix, inhibits NO signaling, and modulates vascular cell behavior with inhibition of angiogenesis (Isenberg et al. 2008). TSP-1 - / - mice had increased retinal vascular density (Wang et al. 2003), and inhibition of TSP-1 improved vascular engraftment of pancreatic islets (Olerud et al. 2008). We also found that serpin B5/maspin known to block VEGF/b-FGF-induced vascular endothelial cell migration and to inhibit angiogenesis (Bailey et al. 2006) was increased. Additional proteins were also increased by glucose such as endostatin and vasohibin. Endostatin inhibits migration and promotes apoptosis specifically in vascular endothelial cells via multiple pathways, notably by reducing expression of the anti-apoptotic protein BCL-2 as well as growth-associated factors (Dhanabal et al. 1999, Shichiri \& Hirata 2001). Endostatin also inhibits phosphorylation of ERK-1 and -2 via the VEGF and FGF pathways and inhibits PEDF production (Shichiri \& Hirata 2001), and downregulates c-myc, which is a protein necessary for endothelial cell migration (Skovseth et al. 2005). Vasohibin is an endothelium-derived negative feedback regulator of angiogenesis expressed by endothelial cells (Watanabe et al. 2004).

Altogether, these results lead us to the hypothesis that elevated glucose could reduce angiogenesis late markers such as VEGF and enhance key markers involved in inhibition of endothelial cell migration and tubular network formation. This was clearly suggested by the reduction of tree-like tubular networks in HUVECs when cultured in high glucose conditions. Results from our study showing alterations of islet angiogenesis could further lead to a progressive loss of $\beta$-cell function. However, reduced VEGF expression and pro-angiogenic factors did not impair the capacity of our islets to mount a strong insulin response to glucose in vitro. Nevertheless, our experiments were performed during short culture periods, and we cannot exclude that reduction in islet angiogenesis could be detrimental to $\beta$-cell function in vivo in the long term. Targeting islet microendothelium might improve $\beta$-cell function. Indeed, Shao et al. (2006) and Lacraz et al. (2009) have recently shown the beneficial effects of calderstan (an AT1R blocker) and IL1Ra treatments on $\beta$-cell function and morphology together with an improvement in islet vascularization in $\mathrm{db} / \mathrm{db}$ mice and GK rats.

In conclusion, we found that glucose interferes with islet angiogenesis key factors, a condition that 
predisposes to dysfunction of blood capillary system surrounding pancreatic islets. Modifications of islet microendothelium after chronic exposure to high glucose concentrations may apply for islet dysfunction for both type 1 and 2 diabetes as well as for islet revascularization during transplantation settings. It seems important to determine whether some antidiabetic drugs or molecules used in the clinics might also be beneficial to the endothelium in order to preserve $\beta$-cell function.

\section{Declaration of interest}

The authors declare that there is no conflict of interest that could be perceived as prejudicing the impartiality of the research reported.

\section{Funding}

This work was supported by INSERM and the Transplantation research network CENTAURE (grant\# P1-L06).

\section{Acknowledgments}

The authors thank the Juvenile Diabetes Research Foundation (grant \#31-2008-416) for providing human islets and supporting this work.

\section{References}

Bailey CM, Khalkhali-Ellis Z, Seftor EA \& Hendrix MJ 2006 Biological functions of maspin. Journal of Cellular Physiology 209 617-624.

Ballian N \& Brunicardi FC 2007 Islet vasculature as a regulator of endocrine pancreas function. World Journal of Surgery 31 705-714.

Bergers G, Brekken R, McMahon G, Vu TH, Itoh T, Tamaki K, Tanzawa $\mathrm{K}$, Thorpe P, Itohara S, Werb Z et al. 2000 Matrix metalloproteinase9 triggers the angiogenic switch during carcinogenesis. Nature Cell Biology 2 737-744.

Chomczynski P \& Sacchi N 1987 Single-step method of RNA isolation by acid guanidinium thiocyanate-phenol-chloroform extraction. Analytical Biochemistry 162 156-159.

Dhanabal M, Volk R, Ramchandran R, Simons M \& Sukhatme VP 1999 Cloning, expression, and in vitro activity of human endostatin. Biochemical and Biophysical Research Communications 258 345-352.

Distler JH, Hirth A, Kurowska-Stolarska M, Gay RE, Gay S \& Distler O 2003 Angiogenic and angiostatic factors in the molecular control of angiogenesis. Quarterly Journal of Nuclear Medicine 47 149-161.

Ehses JA, Lacraz G, Giroix MH, Schmidlin F, Coulaud J, Kassis N, Irminger JC, Kergoat M, Portha B, Homo-Delarche F et al. 2009 IL-1 antagonism reduces hyperglycemia and tissue inflammation in the type 2 diabetic GK rat. PNAS 106 13998-14003.

Huang C, Snider F \& Cross JC 2009 Prolactin receptor is required for normal glucose homeostasis and modulation of beta-cell mass during pregnancy. Endocrinology 150 1618-1626.

Hügl SR \& Merger M 2007 Prolactin stimulates proliferation of the glucose-dependent beta-cell line INS-1 via different IRS-proteins. Journal of the Pancreas 8 739-752.

Isenberg JS, Frazier WA \& Roberts DD 2008 Thrombospondin-1: a physiological regulator of nitric oxide signaling. Cellular and Molecular Life Sciences 65 728-742.

Iwashita N, Uchida T, Choi JB, Azuma K, Ogihara T, Ferrara N, Gerber H, Kawamori R, Inoue M \& Watada H 2007 Impaired insulin secretion in vivo but enhanced insulin secretion from isolated islets in pancreatic beta cell-specific vascular endothelial growth factor-A knock-out mice. Diabetologia 50 380-389.
Lacraz G, Giroix M-H, Kassis N, Coulaud J, Galinier A, Noll C, Cornut M, Schmidlin F, Paul J-L, Janel N et al. 2009 Islet endothelial activation and oxidative stress gene expression is reduced by IL-1Ra treatment in the type 2 diabetic GK rat. PLOS ONE 4 e6963.

Lerman OZ, Galiano RD, Armour M, Levine JP \& Gurtner GC 2003 Cellular dysfunction in the diabetic fibroblast: impairment in migration, vascular endothelial growth factor production, and response to hypoxia. American Journal of Pathology 162 303-312.

Leung PS \& Carlsson PO 2005 Pancreatic islet renin-angiotensin system: its novel roles in islet function and in diabetes mellitus. Pancreas 30 293-298.

Memtsas V, Zarros A \& Theocharis S 2009 Matrix metalloproteinases in the pathophysiology and progression of gynecological malignancies: could their inhibition be an effective therapeutic approach? Expert Opinion on Therapeutic Targets 13 1105-1120.

Neufeld G, Cohen T, Gengrinovitch S \& Poltorak Z 1999 Vascular endothelial growth factor (VEGF) and its receptors. FASEB Journal 13 9-22.

Olerud J, Johansson M, Lawler J, Welsh N \& Carlsson P-O 2008 Improved vascular engraftment and graft function after inhibition of the angiostatic factor thrombospondin-1 in mouse pancreatic islets. Diabetes 57 1870-1877.

Olsson R \& Carlsson PO 2006 The pancreatic islet endothelial cell: emerging roles in islet function and disease. International Journal of Biochemistry and Cell Biology 38 492-497.

Pandya NM, Dhalla NS \& Santani DD 2006 Angiogenesis - a new target for future therapy. Vascular Pharmacology 44 265-274.

Shao J, Iwashita N, Ikeda F, Ogihara T, Uchida T, Shimizu T, Uchino H, Hirose T, Kawamori R \& Watada H 2006 Beneficial effects of canderstan, an angiotensin II type 1 receptor blocker, on beta-cell function and morphology in $\mathrm{db} / \mathrm{db}$ mice. Biochemical and Biophysical Research Communications 344 1224-1233.

Shibuya M 2006 Differential roles of vascular endothelial growth factor receptor-1 and receptor-2 in angiogenesis. Journal of Biochemistry and Molecular Biology 39 469-478.

Shichiri M \& Hirata Y 2001 Antiangiogenesis signals by endostatin. FASEB Journal 15 1044-1053.

Shireman PK 2007 The chemokine system in arteriogenesis and hind limb ischemia. Journal of Vascular Surgery 45 A48-A56.

Skovseth DK, Veuger MJ, Sorensen DR, De Angelis PM \& Haraldsen G 2005 Endostatin dramatically inhibits endothelial cell migration, vascular morphogenesis, and perivascular cell recruitment in vivo. Blood 105 1044-1051.

Wang S, Wu Z, Sorenson CM, Lawler J \& Sheibani N 2003 Thrombospondin-1-deficient mice exhibit increased vascular density during retinal vascular development and are less sensitive to hyperoxiamediated vessel obliteration. Developmental Dynamics 228 630-642.

Watanabe K, Hasegawa Y, Yamashita H, Shimizu K, Ding Y, Abe M, Ohta H, Imagawa K, Hojo K, Maki H et al. 2004 Vasohibin as an endothelium-derived negative feedback regulator of angiogenesis. Journal of Clinical Investigation 114 898-907.

Welsh N, Cnop M, Kharroubi I, Bugliani M, Lupi R, Marchetti P \& Eizirik DL 2005 Is there a role for locally interleukin-1 in the deleterious effects of high glucose or the type 2 diabetes milieu to human pancreatic islets? Diabetes $\mathbf{5 4} 3238-3244$.

Xia Y \& Frangogiannis NG 2007 MCP-1/CCL2 as a therapeutic target in myocardial infarction and ischemic cardiomyopathy. Inflammation E $\mathcal{E}$ Allergy Drug Targets 6 101-107.

Yamamoto T, Ricordi C, Mita A, Miki A, Sakuma Y, Molano RD, Fornoni A, Pileggi A, Inverardi L \& Ichii H $2008 \beta$-Cell specific cytoprotection by prolactin on human islets. Transplantation Proceedings 40 382-383.

Received in final form 5 May 2010

Accepted 26 May 2010

Made available online as an Accepted Preprint 26 May 2010 